\title{
Proteolytic processing of presenilin-1 (PS-1) is not associated with Alzheimer's disease with or without PS-I mutations
}

\author{
Masayasu Okochi ${ }^{\mathrm{a}}$, Kazuhiko Ishii ${ }^{\mathrm{a}, \mathrm{b}}$, Mihoko Usami ${ }^{\mathrm{a}}$, Naruhiko Sahara ${ }^{\mathrm{a}}$, Fuyuki Kametani ${ }^{\mathrm{a}}$, \\ Kikuko Tanaka ${ }^{a}$, Peter E. Fraser ${ }^{c}$, Masaki Ikeda ${ }^{c}$, Ann M. Saunders ${ }^{\mathrm{d}}$, Lydia Hendriks ${ }^{\mathrm{e}}$, \\ Shin-Ichi Shoji ${ }^{b}$, Linda E. Neef, Jean-Jacques Marting, Christine Van Broeckhoven ${ }^{\mathrm{e}}$, \\ Peter H. St. George-Hyslop ${ }^{c}$, Allen D. Roses ${ }^{\mathrm{d}}$, Hiroshi Moria ${ }^{\mathrm{a}}$ * \\ ${ }^{a}$ Department of Molecular Biology, Tokyo Institute of Psychiatry, 2-1-8 Kamikitazawa, Setagayaku, Tokyo 156, Japan \\ ${ }^{b}$ Department of Neurology, Institute of Clinical Medicine, University of Tsukuba, I-1-1 Tennoudai, Tsukuba, Ibaraki 305, Japan \\ ${ }^{c}$ Center for Research into Neurodegenerative Diseases, Department of Medicine (Neurology) and Medical Biophysics, University of Toronto, \\ and Department of Medicine, Division of Neurology, The Toronto Hospital, Toronto, Ont. M5S 1A8, Canada \\ ${ }^{\mathrm{d}}$ Departments of Medicine (Neurology) and Neurobiology, Joseph and Kathleen Bryan Alzheimer Disease Research Center, \\ Duke University Medical Center, Durham, NC 29910, USA \\ ${ }^{\mathrm{e}}$ Laboratory of Neurogenetics, Flanders Interuniversity Institute for Biotechnology (VIB), Born-Bunge Foundation (BBS), \\ University of Antwerp (UIA), Department of Biochemistry, Antwerp, Belgium \\ ${ }^{\mathrm{f}}$ Medical Neurology Branch, NINDS, National Institutes of Health, 9000 Rockville Pike, Bethesda, MD 20892, USA \\ ${ }^{g}$ Laboratory of Neuropathology, Born-Bunge Foundation (BBS), University of Antwerp (UIA), Department of Medicine, Antwerp, Belgium
}

\section{Received 15 October 1997}

\begin{abstract}
Cerebral presenilin-1 protein (PS-1) is normally composed of the amino-terminal fragment (NTF) with $M_{\mathrm{r}} 28$ $\mathrm{kDa}$ and the carboxy-terminal fragment (CTF) with $18 \mathrm{kDa}$. We analyzed human PS-1 in brains with early-onset familial Alzheimer's disease (FAD) with and without PS-1 mutations to study whether mutated PS-1 was abnormally metabolized. Cerebral PS-1 were found to be cleaved into two fragments of NTF and CTF independently of the occurrence of PS-1 mutation in human brains. A small portion of PS-1 was recently found to suffer another processing by caspase- 3 , an apoptosis-related cysteine protease. In contrast to the recent finding that the Volga-German mutation on presenilin-2 (PS-2) affects the increasing caspase-3 PS-2 fragment, the PS-1 mutation did not cause a significant change in PS-1 fragmentation. We conclude that PS-1 fragmentation and other (probably caspase-3mediated) digestion following apoptosis occur independently of PS-1 mutations.
\end{abstract}

(C) 1997 Federation of European Biochemical Societies.

Key words: Alzheimer's disease; Presenilin; Mutation; Caspase-3; CPP32

\section{Introduction}

Alzheimer's disease (AD) is a progressive intellectual failure in elderly people. The causal genes have been identified as presenilin $I(P S-1)$ on chromosome 14q24.3 [1,2], presenilin 2 (PS-2) on chromosome $1 \mathrm{q} 42.1[3,4]$ and $A P P$ on chromosome $21[5,6]$ while the apolipoprotein $E$ allele e4 has been established to be a risk factor located on chromosome 19 [7]. Presenilin genes are members of a novel highly conserved family [8] whose function is not fully understood, and are expressed widely not only in the brain but also in other tissues. In all tissues, PS-1 is found to be essentially cleaved into two frag-

\footnotetext{
*Corresponding author. Fax: (81) (3) 3329-8035.
}

Abbreviations: AD, Alzheimer's disease; FAD, familial AD; PS-1, presenilin-1; PS-2, presenilin-2; NTF, the amino-terminal fragment; CTF, the carboxy-terminal fragment; SDS-PAGE, sodium dodecyl sulfate polyacrylamide gel electrophoresis ments: the amino-terminal fragment (NTF) with $M_{\mathrm{r}} 28 \mathrm{kDa}$ and the carboxy-terminal fragment (CTF) with $M_{\mathrm{r}} 18 \mathrm{kDa}[9$ 12]. This fragmentation was claimed to be affected by the PS-1 mutation $[13,14]$. However, there are reports describing the different effects of the PS-1 mutation on PS- 1 cleavage in cultured cells, animals and human brain $[9,15,16]$. More evidence should accumulate for PS- 1 in human tissues to obtain concrete conclusions. Here, we studied human brains with and without PS-1 mutations to address this question and provide more detailed information on PS-1 processing in brain.

\section{Materials and methods}

\subsection{Preparation of monoclonal and polyclonal antibodies}

Polyclonal and monoclonal antibodies were against NTF and CTF of PS-1, respectively. To prepare NTF antibodies, mice and rabbits were immunized with the synthetic peptide (DNRERQEHNDRRSLGHPEPLSNGRPQ) to produce a polyclonal antibody (AD3N) and a monoclonal antibody (PSN2) [17]. To prepare CTF antibodies, mice and rabbits were immunized with the synthetic peptide (MAEGDPEAQRRVSKNSKYNAESTERESQDTV) to produce polyclonal antibodies (AD3L and $\mathrm{mAD} 3 \mathrm{~L}$ ), respectively [17].

\subsection{Preparation of $P S-1$ from human brains}

The brain tissues of subjects with early-onset FAD analyzed here carried the PS-1 mutations of $\mathrm{Ile}^{143} \mathrm{Thr}$, Met ${ }^{146} \mathrm{Leu}$, His ${ }^{163} \mathrm{Arg}$, $\mathrm{Ala}^{2 / 6} \mathrm{Glu}$ and $\mathrm{Cys}^{110} \mathrm{Tyr}[1,4,18]$. Brain tissues were homogenized with $50 \mathrm{mM}$ Tris-Cl buffer (pH7.6), $150 \mathrm{mM} \mathrm{NaCl}$ containing 0.1 $\mathrm{mM}$ diisopropyl fluoro-phosphate, $0.5 \mathrm{mM}$ phenylmethylsulfonyl fluoride, $1 \mu \mathrm{g} / \mathrm{ml}$ 1-chloro-3-tosylamino-7-amino-2-heptanone, $1 \mu \mathrm{g} / \mathrm{ml}$ antipain, $0.1 \mu \mathrm{g} / \mathrm{ml}$ pepstatin, $1 \mu \mathrm{g} / \mathrm{ml}$ leupeptin (TS buffer) followed by ultracentrifugation at $100000 \times g$ for $20 \mathrm{~min}$ at $4^{\circ} \mathrm{C}$. The supernatant was saved as the soluble fraction. The resultant pellet was sequentially extracted with $1 \%$ Triton X-100 in TS buffer (Tx buffer), $1 \%$ Triton X-100, $0.5 \%$ deoxycholic acid, $0.1 \%$ SDS in TS buffer (RIPA buffer) and $2 \%$ SDS in TS buffer. The membrane fraction extracted with $\mathrm{Tx}$ buffer was further applied onto affinity column coupled to PSN2 or AD3L, specifically eluted with $0.1 \mathrm{M}$ glycine$\mathrm{HCl}(\mathrm{pH} 2.5)$ and immediately neutralized. These monoclonal and polyclonal antibodies (PSN2, AD3N and AD3L) were purified by affinity chromatography coupled with the relevant antigen synthetic peptides.

\subsection{Sodium dodecyl sulfate polyacrylamide gel electrophoresis \\ (SDS-PAGE) and immunoblotting}

SDS-PAGE was carried under reducing conditions, and proteins in 
gels were transferred on PVDF membrane (MSI). The membrane was blocked with 3\% gelatin, incubated with PSN2 followed by the horseradish peroxidase (HRP)-conjugated second antibody. The color was developed with 4-chloro-1-naphthol.

\subsection{Quantitation of protein concentration}

Protein concentration was determined by measuring the absorption at $562 \mathrm{~nm}$ using the BCA protein assay kit (Pierce, IL).

\section{Results and discussion}

\subsection{Gel electrophoretic analysis of human brain PS-1}

To get a specific and high recovery of PS-1 from human brains, we used the two-step detection method to identify PS1. We used the two antibodies for immunoprecipitation as the first step and Western blotting as the second step. AD3N and PSN2 were used to detect NTF while AD3L and mAD3L were used to detect CTF. As seen in Fig. 1a, NTF in aged normal brains was found predominantly in the membrane fraction that was obtained with $\mathrm{Tx}$ buffer. CTF was found both in the membrane and partly in the cytoskeleton fractions. This result suggests two possibilities. CTF was somewhat insoluble as compared with NTF. Alternatively, a portion of CTF was associated with filamentous cytoskeletons such as neurofilaments. Similar results were obtained in PS1 derived from brains with sporadic AD (Fig. 1b) and earlyonset familial AD with PS-1 mutation ( $\mathrm{His}^{163} \mathrm{Arg}$ ) (Fig. 1c). These data could provide one clear conclusion that the PS-1 mutation (His ${ }^{163} \mathrm{Arg}$ ) did not affect PS-1 processing to support another FAD case with the PS-1 mutation (Gly ${ }^{384}$ Ala)
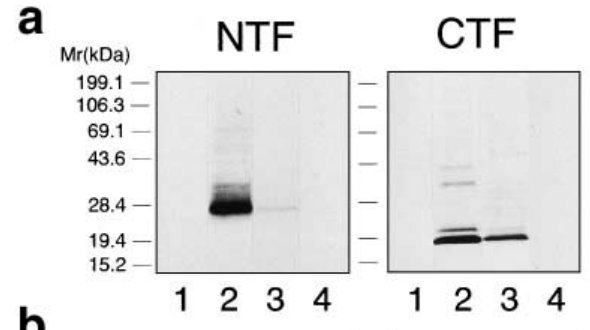

b

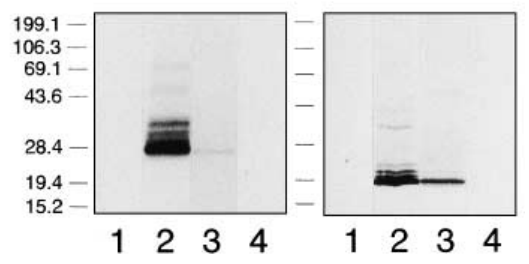

C

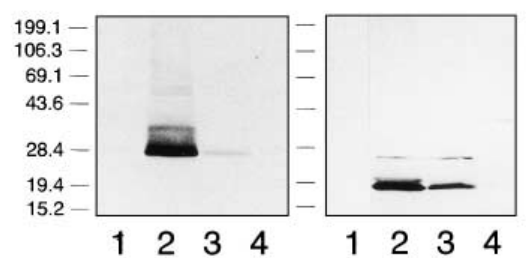

Fig. 1. PS-1 $\mathrm{NH}_{2}$ fragment (NTF) and $\mathrm{COOH}$ fragment (CTF) in subcellular fraction of human brains. Brain cortices were homogenized and separated into four fractions (see Section 2). Each fraction was immunoprecipitated with affinity-purified AD3N or AD3L followed by gel electrophoresis/Western blotting with PSN2 or mAD3L, respectively. a: aged normal, b: sporadic $A D$ and $c$ : familial AD with PS-1 mutation (His ${ }^{163} \mathrm{Arg}$ ). Lane 1: supernatant fraction extracted with TS buffer; lane 2: supernatant fraction extracted with $1 \%$ Triton $\mathrm{X}-100$; lane 3 : supernatant fraction extracted with RIPA buffer; lane 4: RIPA buffer precipitate fraction. a
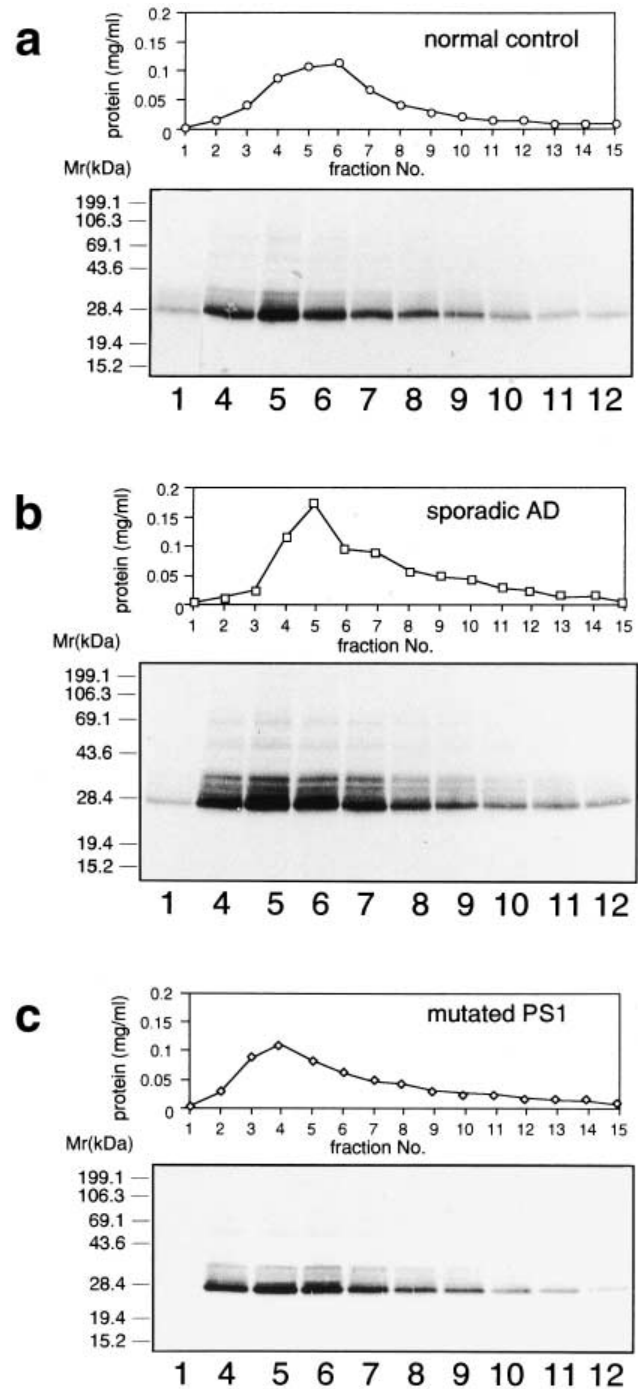

Fig. 2. Immunoaffinity column chromatography of PS-1 fragments (NTF) in normal, sporadic and familial AD brains. Triton X-100 supernatant fractions from brains of (a) aged normal subject $(0.4 \mathrm{~g})$, sporadic AD $(0.5 \mathrm{~g})$ and familial AD with PS-1 mutation $\left(\mathrm{His}^{163} \mathrm{Arg}\right)(0.25 \mathrm{~g})$ were applied onto an affinity-purified AD3Ncoupled affinity column. The PS-1-containing fraction was eluted with $0.1 \mathrm{M}$ glycine-HCl, pH 2.5 and immunoblotted with PSN2.

[16] unlike in previous studies performed in cultured cells $[13,14]$.

We next attempted to quantitatively obtain PS-1 fragments. For this purpose, we prepared an immunoaffinity column to obtain the PS-1 fragment. Synthetic peptides used as antigens (see Section 2) were coupled with Sepharose 4B. Antibodies were applied onto this affinity column followed by washing with PBS and eluted with $0.1 \mathrm{M}$ glycine-HCl, $\mathrm{pH} 2.5$. The eluent was immediately neutralized with $2 \mathrm{M}$ Trizma. Purified antibodies were then coupled to Sepharose 4B. The membrane fraction from human brains was applied onto a purified antibody-coupled affinity column and eluted (Fig. 2). As seen in protein concentrations in Fig. 2, the amounts of PS-1 fragment were different. However, the molecular compositions of PS-1 were essentially identical as seen in the result obtained from the immunoprecipitation experiment (Fig. 1). 


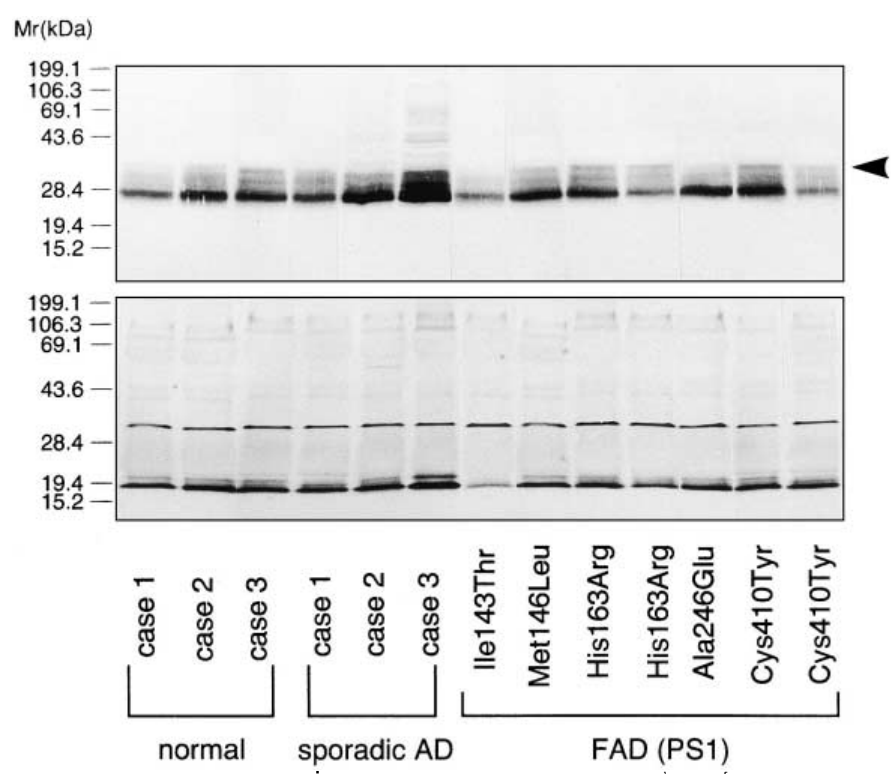

Fig. 3. PS-1 fragments (NTF and CTF) in normal, sporadic and familial AD brains. PS-1 fragments (NTF and CTF) were extracted and partially purified in a semi-quantitative manner and examined by Western blotting as described in Section 2 or in the legend to Fig. 2. Seven independent FAD cases with five different PS-1 mutations were examined. The PS-1 mutations examined are $\mathrm{Ile}^{143} \mathrm{Thr}$, Met ${ }^{146} \mathrm{Leu}, \mathrm{His}{ }^{163} \mathrm{Arg}$, $\mathrm{Ala}^{246} \mathrm{Glu}$ and $\mathrm{Cys}^{410}$ Tyr. Note the presence of the largest band (caspase-3 fragment) of PS-1 with $M_{\mathrm{r}} 34 \mathrm{kDa}$ (arrowhead).

\subsection{Effect of PS-I mutations on PS-1 fragmentation in brains with early-onset familial AD bearing PS-1 mutations}

We provisionally concluded that PS-1 processing occurred independent on the mutation using the single case ( $\mathrm{His}^{163} \mathrm{Arg}$ ). This result confirmed a previous finding for a Belgian PS-1 mutation [16]. To see whether this conclusion is universal, we examined PS-1 in familial AD brains (seven independent cases) with different mutation sites and different pedigree cases with the same mutation site. We prepared NTF and CTF that were derived from subjects with normal aged, sporadic $\mathrm{AD}$ and seven independent familial $\mathrm{AD}$ according to the method in Fig. 2. As shown in Fig. 3, we observed that human PS-1 was cleaved into two fragments (NTF and CTF) independent of the PS-1 mutation. It is noteworthy that this observation was highly constant and was not influenced by the mutation site from exon 5 to exon 12 of PS-1 [2] and the two fragments (NTF and CTF) were similarly found in both sporadic and familial AD. The amount of PS-1 was higher in FAD brains ( $36 \mathrm{fmol} / \mathrm{mg}$ of protein; $n=7$ ) than sporadic AD brains (16 fmol/mg of protein; $n=44)$ based on quantitative densitometric analysis of Western blotting. Although the number of FAD cases is small, this result may be interesting if we consider the possibility that the $P S-1 \mathrm{mu}-$ tation affects gene expression of $P S-1$.

\subsection{Effect of PS-1 mutations on the PS-1 fragment of $M_{r} 34 \mathrm{kDa}$ in brains with early-onset familial AD bearing PS-1 mutations}

As seen in Fig. 3, we observed NTF with higher molecular weight beside NTF with $M_{\mathrm{r}} 28 \mathrm{kDa}$. The largest size of PS-1 NTF species was estimated to be $34 \mathrm{kDa}$. This band could be the caspase-3 fragment that was recently reported [19-21]. This fragment was found to be evidently removed by zVAD, a broad-spectrum inhibitor for most mammalian interleukin-1 $\beta$-converting enzyme ICE/Ced-3 proteases (caspases), and zDEVD-fmk, a more selective inhibitor of caspase-3 (CPP32) family proteases (caspase-3, -6 and -7)
[22,23]. More recently, its CTF was isolated and sequenced, showing the presence of the consensus site for caspase- 3 cleavage [24]. It is likely from the point of view of molecular weight that the present PS- 1 fragment with $M_{\mathrm{r}} 34 \mathrm{kDa}$ is a caspase-3 fragment although we have no evidence to support it. As the caspase-3 fragment of PS-2 was reported to be linked with the Volga-German mutation ( $\mathrm{Asn}^{141} \mathrm{Ile}$ ) of $P S-2$ located on chromosome 1q42.1 [3,4,17], we next examined the effect of PS-1 mutations on this PS- 1 fragment. As A $\beta$ production was influenced by the PS-1 mutation sites [25-28], it is interesting to examine whether the $34 \mathrm{kDa}$ NTF (caspase- 3 fragment) is altered in a mutation site-dependent manner. We studied PS-1 in brains from different pedigrees with FAD bearing different PS-1 mutations.

Fig. 4 shows the ratio of $34 \mathrm{kDa} N T F / 28 \mathrm{kDa} N T F$. The effect seemed to be very dependent on the mutation site. Tak-

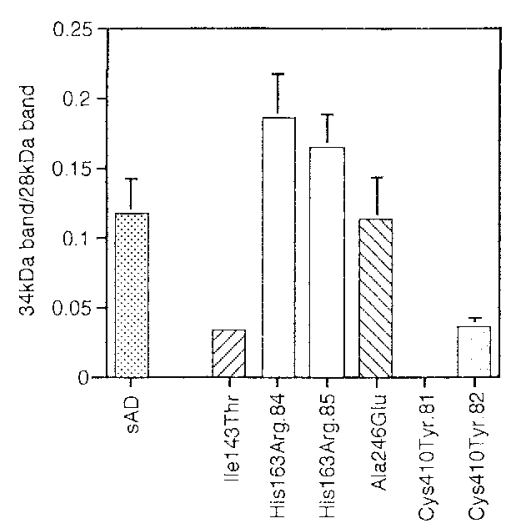

Fig. 4. Effect of mutation site on PS-1 on the ratio of $34 \mathrm{kDa}$ NFT (caspase-3 fragment)/28 kDa NTF. The immunoreactive PS-1 NTF bands with $M_{\mathrm{r}} 34 \mathrm{kDa}$ and $28 \mathrm{kDa}$ were quantitated with a densitometer (Shimadzu CS-9000, Kyoto). Sporadic AD cases $(n=44)$ and FAD cases $(n=7)$ were analyzed and the ratio of $34 \mathrm{kDa} \mathrm{NTF} /$ $28 \mathrm{kDa} \mathrm{NTF}$ is shown as the average \pm S.E. of three independent analyses. 
ing into consideration experimental deviation, the present data may suggest that the $34 \mathrm{kDa}$ NTF (caspase- 3 fragment) of PS-1 was not tightly associated with PS-1 mutations. We could not find a significant difference in the ratio of this 34 $\mathrm{kDa}$ NTF/28 kDa NTF between sporadic AD and familial $\mathrm{AD}$ bearing PS-1 mutations (data not shown). In spite of the present results on PS-1, an involvement of caspase- 3 in AD pathogenesis may be important to understand the pathogenesis of FAD with PS-2 mutations. Caspase-3 is widely believed to play a role in mammalian apoptosis (programmed cell death), an evolutionarily conserved form of cellular suicide. If this enzyme is related to $\mathrm{AD}$ pathogenesis, it is very interesting because it gives hope for drug treatment for $\mathrm{AD}$ patients. A recent report is suggestive of the involvement of caspase-3 in the pathological metabolism of PS-2 [19] but this still needs to be studied more. It is worth noting that the expression amounts of presenilin (PS-1 and PS-2) themselves could be a potent factor to influence the processing of presenilin as previously described [9]. Therefore, the site-specific effects of the mutations seen in Fig. 4 might come from the different amounts of mutated $P S-I$ expressed in human brains. These results on the $P S-1$ mutations are different from previous ones in cultured cells or transgenic mice $[9,13,14]$. We believe that both their data $[9,13,14]$ and our data $[15,16]$ are true since the apparent discrepancy comes from the physiological expression or experimental expression. Thus, the level of $P S-1$ gene expression is a critical issue if we consider the possibility that the full-sized PS-1 plays a different role from PS-1 fragments or the gene product is in competitive balance with other molecules. It is suggested that the PS-1 mutation be considered at least in the relation among PS-1, PS-2, and $\beta$ APP but it has no influence on the conventional and $34 \mathrm{kDa}$ NTF-generating (caspase-3) cleavage of mutated PS-1 at least in human brains.

Acknowledgements: This work was supported by Grants-in-Aid for Scientific Research to H.M. from the Ministry of Education, Science and Culture, Japan. Thanks are due to the Naitoh Foundation, Foundation for Total Health Promotion, Mitsui Life Social Welfare Foundation and Sasakawa Foundation, Chiyoda Mutual Life Foundation to H.M., the Medical Research Council of Canada, the American Health Assistance Foundation, the Alzheimer Association of Ontario, and the Canadian Genetic Disease Network to P.H.St.G.-H. and the Fund for Scientific Research-Flanders (Belgium) (FWO), the Flemish Biotechnology Programme (COT-004), the DWTC InterUniversity Attraction Poles (IUAP) and European Union BIOTECH Grant CT96 to C.V.B. and J.-J.M.

\section{References}

[1] Sherrington, R., Rogaev, E.I., Liang, Y., Rogaeva, E.A., Levesque, G., Ikeda, M., Chi, H., Lin, C., Li, G., Holman, K., Tsuda, T., Mar, L., Foncin, J.F., Bruni, A.C., Montesi, M.P., Sorbi, S., Rainero, I., Pinessi, L., Nee, L., Chumakov, I., Pollen, D., Brookes, A., Sanseau, P., Polinski, R.J., Wasco, W., Da Silva, H.A.R., Haines, J.L., Pericak-Vance, M.A., Tanzi, R.E., Roses, A.D., Fraser, P.E., Rommens, J.M. and St. George-Hyslop, P.H. (1995) Nature 375, 754-760.

[2] Alzheimer's Disease Collaborative Group (1995) Nature Genet. $11,219-222$

[3] Levy-Lahad, E., Wasco, W., Poorkaj, P., Romano, D.M., Oshima, J., Pettingell, W.H., Yu, C.E., Jondro, P.D., Schmidt, S.D., Wang, K., Crowley, A.C., Fu, Y.-H., Guenette, S.Y., Galas, D., Nemens, E., Wijsman, E.M., Bird, T.B., Schellenberg, G.D. and Tanzi, R.E. (1995) Science 269, 973-977.

[4] Rogaev, E.I., Sherrington, R., Rogaeva, E.A., Levesque, G., Ikeda, M., Liang, Y., Chi, H., Lin, C., Holman, K., Tsuda, T., Mar,
L., Sorbi, S., Nacmias, B., Piacentini, S., Amaducci, L., Chumakov, I., Cohen, D., Lannfelt, L., Fraser, P.E., Rommens, J.M. and St. George-Hyslop, P.H. (1995) Nature 376, 775-778.

[5] Kang, J., Lamaire, H.G., Unterbeck, A., Salvaum, J.M., Masters, C.L., Crzeschik, K.H., Multhaup, G., Beyreuther, K. and Muller-Hill, B. (1987) Nature 325, 733-736.

[6] Goate, A., Chartier-Harlin, M.C., Mullan, M., Brown, J., Crawford, F., Fidani, L., Giuggra, L., Haynes, A., Irving, N., James, L., Mant, R., Newton, P., Rooke, K., Roques, P., Talbot, C., Pericak-Vance, M., Roses, A., Williamson, R., Rossor, M., Owen, M. and Hardy, J. (1991) Nature 349, 704-706.

[7] Corder, E.H., Sauders, A.M., Strittmatter, W.J., Schmechel, D.E., Gaskell, P.C., Small, G.W., Roses, A.D., Haines, J.L. and Pericak-Vance, M.A. (1993) Science 261, 921-923.

[8] Levitan, D. and Greenwald, I. (1995) Nature 377, 351-354.

[9] Thinakaran, G., Borchelt, D.R., Lee, M.K., Slunt, H.H., Spitzer, L., Kim, G., Ratovitsky, T., Davenport, F., Nordstedt, C., Seeger, M., Hardy, J., Allan, I.L., Gandy, S.E., Jenkins, N.A., Copeland, N.G., Price, D.L. and Sisodia, S.S. (1996) Neuron 17, 181-190.

[10] Borchelt, D.R., Thinakaran, G., Eckman, C.B., Lee, M.K., Davenport, F., Ratovitsky, T., Prada, C.M., Kim, G., Seekins, S., Yager, D., Slunt, H.H., Wang, R., Seeger, M., Levey, A.I., Gandy, S.E., Copeland, N.G., Jenkins, N.A., Price, D.L., Younkin, S.G. and Sisodia, S.S. (1996) Neuron 17, 1005-1013.

[11] Doan, A., Thinakaran, G., Borchelt, D.R., Slunt, H.H., Ratovitsky, T., Podlisny, M., Selkoe, D.J., Seeger, M., Gandy, S.E., Price, D.L. and Sisodia, S.S. (1996) Neuron 17, 1023-1030.

[12] Kovacs, D.M., Fausett, H.J., Page, K.J., Kim, T.-W., Moir, R.D., Merriam, D.E., Hollister, R.D., Hallmark, O.G., Mancini, R., Felsenstein, K.M., Hyman, B.T., Tanzi, R.E. and Wasco, W. (1996) Nature Med. 2, 224-229.

[13] Mercken, M., Takahashi, H., Honda, T., Sato, K., Murayama, M., Nakazato, Y., Noguchi, K., Imahori, K. and Takashima, A. (1996) FEBS Lett. 389, 297-303.

[14] Murayama, O., Honda, T., Mercken, M., Murayama, M., Yasutake, K., Nihonmatsu, N., Nakazato, Y., Michel, G., Song, S., Sato, K., Takahashi, H. and Takashima, A. (1997) Neurosci. Lett. 229, 61-64.

[15] Yamamoto, A., Sahara, N., Usami, M., Okochi, M., Kondo, T., Kametani, F., Tanaka, K., Yahagi, Y., Shirasawa, T., Itoyama, Y. and Mori, H. (1996) Biochem. Biophys. Res. Commun. 226, 536-541.

[16] Hendriks, L., Thinakaran, G., Harris, C.L., Jonghe, C.D., Martin, J.-J., Sisodia, S.S. and Broeckhoven, C.V. (1997) NeuroReport 8, 1717-1721.

[17] Sahara, N., Yahagi, Y., Takagi, H., Kondo, T., Okochi, M., Usami, M., Shirasawa, T, and Mori, H. (1996) FEBS Lett. $381,7-11$

[18] Cruts, M., Backhovens, H., Wang, S.-Y., Gassen, G.V., Theuns, J., Jonghe, C.D., Wehnert, A., Voecht, J.D., Winter, G.D., Cras, P., Bruyland, M., Datson, N., Weissenbach, J., den Dunnen, J.T., Martin, J.-J., Hendriks, L. and Van Broeckhoven, C. (1995) Hum. Mol. Genet. 4, 2363-2371.

[19] Kim, T.-W., Pettinggell, W.H., Jung, Y.-K., Koacs, D.M. and Tanzi, R.E. (1997) Science 277, 373-376.

[20] Hartmann, H., Busciglio, J., Baumann, K.-H., Staufenbiel, M. and Yankner, B.A. (1997) J. Biol. Chem. 272, 14505-14508.

[21] Seeger, M., Nordstedt, C., Petanceska, S., Kovacs, D., Gouras, G.K., Hahne, S., Fraser, P., Levesque, L., Czernik, A.J., St George-Hyslop, P., Sisodia, S.S., Thinakaran, G., Tanzi, R.E., Greengard, P. and Gandy, S. (1997) Proc. Natl. Acad. Sci. USA $94,5090-5094$.

[22] Alnemri, E.S., Livingston, D.J., Nicholson, D.W., Salvesen, G., Thornberry, N.A., Wong, W.W. and Yuan, J. (1996) Cell 87, 171.

[23] Martin, S.J. and Green, D.R. (1995) Cell 82, 349-352.

[24] Loetschner, H., Deuschle, U., Brockhaus, M., Reinhardt, D., Nelboeck, P., Mous, J., Grunberg, J., Haass, C. and Jacobsen, H. (1996) J. Biol. Chem. 272, 20655-20659.

[25] Scheuner, D., Eckman, C., Jensen, M., Song, X., Citron, M., Suzuki, N., Bird, T.D., Hardy, J., Hutton, M., Kukull, W., Larson, E., Levy-Lahad, E., Viitanen, M., Peskind, E., Poorkaj, P., Schellenberg, G., Tanzi, R., Wasco, W., Lannfelt, L., Selkoe, D. and Younkin, S. (1996) Nature Med. 2, 864-870. 
[26] Duff, K., Eckman, C., Zehr, C., Yu, X., Prada, C.-M., Perez-Tur, J., Hutton, M., Buee, L., Harigaya, Y., Yager, D., Morgan, D., Gordon, M.N., Holcomb, L., Refolo, L., Zenk, B., Hardy, J. and Younkin, S. (1996) Nature 383, 710-713.

[27] Lemere, C.A., Lopera, F., Kosik, K.S., Lendon, C.L., Ossa, J., Saido, T.C., Yamaguchi, H., Ruiz, A., Martinez, A., Madrigal, L., Hincapie, L., Arango, J.C., Anthony, D.C., Koo, E.H., Goate, A.M., Selkoe, D.J. and Arango, J.C. (1996) Nature Med. 2, 1146-1150.
[28] Citron, M., Westaway, D., Xia, W., Carlson, G., Diehl, T., Levesque, G., Johnson-Wood, K., Lee, M., Seubert, P., Davis, A., Kholodenko, D., Motter, R., Sherrington, R., Perry, B., Yao, H., Strome, R., Lieberburg, I., Rommens, J., Kim, S., Schenk, D., Fraser, P., St. George-Hyslop, P. and Selkoe, D.J. (1997) Nature Med. 3, 67-72. 